\title{
A Study of a Korean Speaking Class Using Online Platforms During COVID-19
}

Eunmi Yu, Ankara University, Department of Korean Language and Literature, Ankara, Turkey, Email: eyu@ankara.edu.tr

Online education consists of courses conducted through the internet. In these courses, students generally conduct e-learning management and can view their course content and academic progress as well as communicate with their classmates and teachers. Although online classes require a greater amount of motivation compared to a classroom-based course, it became a necessity out of precaution concerning the coronavirus disease. Turkey, like other countries, wanted to continue students' education, but COVID-19 required an educational shift to online systems to prevent the spread of the disease. Although online education does not require a specific space for learning, it does require students to be self-paced and have a peaceful environment. It also requires the preparation of all lecture materials. Teachers and students both should be attentive to facilitate successful delivery and acquisition of knowledge. Online education is an effective way of teaching, but is less effective in comparison to traditional education. In this study, the author would like to share some findings and suggestions for effective online classes for students studying Korean as a foreign language in Turkey while participating in an online Speaking Korean class during the coronavirus period.

Keywords: Online Education, Korean Speaking, COVID-19

\section{Introduction:}

COVID-19 has created unprecedented social, health, educational, and economic crises across the whole world (Grubic et al., 2020; Sundarasen et al., 2020). Turkey has also been affected as its neighbouring countries have suffered. This country was affected swiftly and relentlessly. As shown in the research study of the effect of the first coronavirus disease found in 2019, the educational system has also been affected greatly worldwide (Toquero, 2020). Thousands of schools, colleges and universities were closed for the safety of students and online education 
became a substitutional method. All students and teachers faced a lot of problems as a result since these changes were made abruptly without sufficient preparation, but it was necessary as a means of protecting the lives and health of the community. However, the effectiveness of online education was dependent on the degree of digitalisation of the country; it would be more effective for a digitally advanced country while it would be ineffective for a less digitally developed country (Adnan and Anwar, 2020). Turkey wanted to continue student learning, so schools started teaching online. Each institute has started teaching courses online through mobile and web apps. Although it was difficult to transfer all teaching methodologies, content data and other activities like assessment and observation online, it was also necessary to continue moving forward with students' education (Isbell, 2018). Online studies may prove effective, but there are many issues to face and sort out that both teachers and students have to overcome. Online courses do not require a fixed place, but they do require a place suitable for learning without many distractions (DiBiase, 2000; Dhawan, 2020).

In particular, besides the limitations and worries about online education, there are still unrivalled advantages during the COVID-19 pandemic. The fact that lectures are recorded would be the first reason why we cannot give up these days. In online studies, the lectures are recorded for students to listen to the previous class for future reference (Brecht, 2012). Any time they wish to learn or review the material, they can access their lectures and gain the benefits. It is more reliable for those who may have missed their lectures for any number of reasons, including family issues. Through recorded lectures, students can come together and discuss the topics with each other and help the intellectually disabled students who are struggling with learning the class material. New media and servers are being developed for online educational techniques for better results in education and its assessment (Proshkova, 2020). There is also a requirement for the lecturer to prepare the lectures in a reliable manner.

Teachers prepare and plan the lectures in advance so they can overcome their difficulties compared to face-to-face instruction. They prepare the lecture, save the data for later, and also provide content, data, or notes to their students in softcopy. Teachers show the content during the lecture step by step through more convenient apps on web and mobile. They describe and explain it to the students clearly (Verawardina et al., 2020). Moreover, health and safety is the most important thing. As we all know today, maintaining one's health is greatly important. The whole world is facing the same serious disease and it is very difficult to receive an education in a proper institution regularly. Online systems, then, are an easy and lifesaving way of still getting an education. All institutions are trying to teach their courses through online education apps to prioritise everyone's health and safety (Proshkova, 2020). However, neither students nor teachers are familiar with online classes, so it is necessary to constantly think about what is needed to make online courses more effective.

This study aimed to suggest items that should be considered when conducting foreign language education during the coronavirus for students studying Korean as a foreign language. Students 
who had already experienced online classes for one semester were surveyed to examine their opinions on online classes and to accordingly re-design class types and structures for better performance. In addition, the strengths and weaknesses of the online language education were examined through students enrolled in a Korean speaking class. Lastly, I tried to present several considerations for teaching online foreign language classes during the coronavirus period.

\section{Methodology}

This study began with a survey of 23 students who studied Korean as a second foreign language at a university. They are currently enrolled in their second year in 2020 and are taking classes online after last semester because of the coronavirus situation. Therefore, this survey result can be said to include the evaluation of online classes that have been taken by those students since last fall semester. The students who participated in the survey are taking the Speaking Korean course during the fall semester of 2020, and this class is held online once a week. According to the timetable, the class time is 3 hours with 3 credits allotted.

The questions used in the survey are shown in Table 1 below. All questions have been intentionally prepared by the author to determine the direction of the Speaking Korean class. The survey was conducted during the first hour of online class and student responses were anonymous. This survey was conducted to understand the students' online environment and to find out the students' thoughts about online classes. All questionnaires were made to be multiple choice and students were allowed to choose the most appropriate answer according to their opinion. In addition, Table 1 presents not only the questionnaire survey, but also students' responses as a percentage.

Table 1. Survey questions and the answer percentage

\begin{tabular}{|c|c|c|}
\hline No & Question & Answer (response percentage) \\
\hline 1 & $\begin{array}{l}\text { How do you access your online } \\
\text { class? }\end{array}$ & $\begin{array}{l}\text { (1) Desktop PC (48) } \\
\text { (2) Laptop (30) } \\
\text { (3) Tablet (9) } \\
\text { (4) Smartphone (13) } \\
\text { (5) Other (0) }\end{array}$ \\
\hline 2 & $\begin{array}{l}\text { Where do you access your online } \\
\text { class? }\end{array}$ & $\begin{array}{l}\text { (1) At home (96) } \\
\text { (2) At a café (4) } \\
\text { (3) Other (0) }\end{array}$ \\
\hline 3 & $\begin{array}{l}\text { Are you satisfied with the current } \\
\text { online learning environment? }\end{array}$ & $\begin{array}{l}\text { (1) Totally agree (26) } \\
\text { (2) Agree (43) } \\
\text { (3) Average (26) } \\
\text { (4) Not enough (0) } \\
\text { (5) Never enough (4) }\end{array}$ \\
\hline
\end{tabular}


International Journal of Innovation, Creativity and Change. www.ijicc.net

Volume 15, Issue 2, 2021

\begin{tabular}{|c|c|c|}
\hline 4 & $\begin{array}{l}\text { Do you think the lecture duration } \\
\text { ( } 40 \text { minutes as } 1 \text { class hour) is } \\
\text { suitable? }\end{array}$ & $\begin{array}{l}\text { (1) Totally agree (35) } \\
\text { (2) Agree (13) } \\
\text { (3) Average (17) } \\
\text { (4) Not enough (22) } \\
\text { (5) Never enough (13) }\end{array}$ \\
\hline 5 & $\begin{array}{l}\text { Do you clearly understand the } \\
\text { course contents in your online } \\
\text { class? }\end{array}$ & $\begin{array}{l}\text { (1) Totally agree (35) } \\
\text { (2) Agree (35) } \\
\text { (3) Average (22) } \\
\text { (4) Not enough (4) } \\
\text { (5) Never enough (4) }\end{array}$ \\
\hline 6 & $\begin{array}{l}\text { What is your preferred teaching } \\
\text { method from your teachers? }\end{array}$ & $\begin{array}{l}\text { (1) Both sharing PPT and writing on it (57) } \\
\text { (2) Opening a window to write (9) } \\
\text { (3) Using a real whiteboard (4) } \\
\text { (4) Sharing PPT and explaining with voice (26) } \\
\text { (5) Others (0) }\end{array}$ \\
\hline 7 & $\begin{array}{l}\text { How do you use your camera } \\
\text { during lecture? }\end{array}$ & $\begin{array}{l}\text { (1) I prefer to turn on (17) } \\
\text { (2) I prefer to turn off (57) } \\
\text { (3) No preference (26) }\end{array}$ \\
\hline 8 & $\begin{array}{l}\text { How do you prefer your teacher's } \\
\text { camera to be used during lecture? }\end{array}$ & $\begin{array}{l}\text { (1) Prefer to be turned on (60) } \\
\text { (2) Prefer to be turned off (0) } \\
\text { (3) No preference }(40)\end{array}$ \\
\hline 9 & $\begin{array}{l}\text { What is the advantage of an online } \\
\text { class? }\end{array}$ & $\begin{array}{l}\text { (1) Safety (50) } \\
\text { (2) Comfortable atmosphere (40) } \\
\text { (3) Flexibility (35) } \\
\text { (4) Chances to talk with lecturer (13) } \\
\text { (5) Excuses not to attend class (8) }\end{array}$ \\
\hline 10 & $\begin{array}{l}\text { What is the drawback of an online } \\
\text { class? }\end{array}$ & $\begin{array}{l}\text { 1) Technical problems (20) } \\
\text { (2) Less concentration (36) } \\
\text { (3) Noise from neighbour (8) } \\
\text { (4) Cannot meet friends (18) } \\
\text { (6) No chance to ask teacher questions (18) }\end{array}$ \\
\hline
\end{tabular}

\section{Results and Discussion}

As we look at the results of the survey shown in Table 1, it can be seen that most of the students participate in online classes at home using desktop PCs and laptop computers. It is a natural outcome for all students to participate in classes at home because of the nationwide movement restrictions and school closures. Overall, students' satisfaction with online classes can be viewed as positive. However, there were considerable opinions that there was not enough class time. It can be seen that the students are absolutely in favour of the class using Microsoft PowerPoint presentations as the main method of teaching. When it comes to using cameras 
during class, they don't want to turn on their cameras, but the opinion that they want to see the teacher's lectures through the screen was clear. This is probably because they want to learn the correct pronunciation through the shape of the teacher's mouth or face, as it is a language class. In addition, the primary advantage of online classes that was chosen was the safe and comfortable learning environment, and after that, students selected the fact that they could listen to the stored lectures in their free time. Lastly, regarding the disadvantages of online classes, students selected the lack of concentration on the class, technical problems such as internet speed, and the fact that they cannot meet friends or have the opportunity to talk directly with the teacher.

Considering these survey results, the general difficulties faced by second-year college students who are learning Korean as a foreign language can be summarised as follows:

(1) Speaking activities are limited in an online class

The major issue in the Speaking Korean online class is the lack of speaking activities. Students need to learn how to pronounce words and how to manipulate the mouth to make the proper sounds. Many times, teachers use one-to-one instruction to correct the pronunciation of the students. However, the online course limits the teacher's access to the students and makes it more difficult to deliver all the details of Korean speaking techniques. Compared to other foreign language activities, such as writing, reading, or listening, the concept of speaking is more difficult to teach online. At the same time, students have limited time to practice what they learned during the class. There is a risk of students creating bad habits in their language pronunciation if it is not corrected immediately (Demirzen and Topal, 2015). Teachers should be very creative to overcome this issue.

(2) Preparing new lecture materials/slides for online courses is difficult

For each new lecture, teachers have to prepare the data and make the slides to explain it step by step for an online learning environment. It would be a very new situation for most foreign language instructors. For those who faced this situation without any preparation, they would not even have time to write or prepare the online lesson materials. Teachers have to prepare the lecture slides and collect the data in a format suitable for delivering it in front of a computer monitor. How could they prepare this properly in a very short time? It's difficult to gather all the data before delivering and providing the lecture to students properly.

(3) Some students have difficulty accessing the internet

Another difficulty is the problem of not all students having access to the internet. Some students still have no access to the internet because of poverty or due to some areas of the country being underdeveloped, etc. Without internet, they cannot continue their education and courses online. 
For online studies, it is very important for all students to have proper access to the internet. Governments and institutions should take care to address this difficulty and try to sort out this issue to ensure a better future for their young citizens. However, there are real limitations in trying to solve these issues.

In addition, online learning requires strong motivation from both sides. Distance learning is not suitable for intellectually disabled students to develop proper communication skills. Students cannot prove their best performance in practical knowledge online. Another major problem is user identification. Not every student has access to the internet. Students cannot maintain their pace of learning without some self-control. Communication skills, confidence, and teamwork skills cannot be developed easily online. Managing all of the content is another issue. Some students do not do their work honestly, as teachers have no idea who is or isn't attending the class (Woon and May, 2020; Mirkholikovna, 2020). Disabled students, especially intellectually disabled students, are not in a position to understand what their teachers are explaining, and that may cause social isolation as well.

To overcome the difficulties of taking online classes, the following actions have been applied to the Speaking Korean course. Firstly, the class will be divided into several small groups, and each group will be instructed to make a group speaking activity by themselves. It will be a homework assignment for students, and they will record their tasks as a group and upload them. As a group, the students can gather their questions or tasks into one form by discussing the content with each other. They can then compile and upload them during the online lesson. It will then be easy for teachers to know the questions of each group. Secondly, the most reliable multimedia and apps for class material were collected and utilised to attract students' attention as much as possible. Teachers can find many animations, video clips, or photos for their online lectures so that students might gain more knowledge from them. Moreover, teachers can try to apply several educational games that can be used in online classes as a class activity, like quiz programs, short tests, oral responses, and written multiple choice questions. Thirdly, terminology used in the class was recorded with lectures through a chat room function, because some students could not clearly hear the lecture. This may be caused by limited recording techniques or an internet speed issue.

Online courses and studies, especially for secondary schools, can be quite beneficial in keeping students busy and actively learning. However, it may be more costly compared to traditional classes. Through a research form given to the public, the results revealed that online learning can be beneficial for students, but most people are not aware of it or have no internet access, especially in developing countries. A student with significant gaps in their learning will not be able to cognitively catch up to their peers in terms of intelligence and academic performance. The research form responses highlight the effects of online learning on students' academic performance at the secondary level. Online learning teaches time management skills and flexibility to students and motivates them to focus on their own activities without help from 
others. These skills will be useful for them when they are adapting to online courses. The hardest part about teaching students in online classes is the continuous distractions around the teachers and students. Some distractions mostly happen at home, like family members, electronic devices, or environmental noise. Many students still do not have a proper place to learn online. But for now, we are bound to this online education for all students due to COVID19. Therefore, several suggestions could be considered for more efficient and effective online learning.

Today, online education is important as well as necessary, so we have to try to make it more effective and convenient. Online programs should be effective to ensure a better future for students through gaining a valid education. It will be more effective when lectures can be designed for weekly progress. Homework and school activities should be given to students for motivation or assessment. Teachers can judge if students are doing their work properly and attain the knowledge purposefully through assigning them homework and activities. It may be helpful for students when they get the recorded lecture and use them during their activities or assignments. It will be helpful for students to complete their tasks through recorded lectures and homework. Short activities during online classes can be effective, such as short tests, oral responses, written quizzes, and multiple-choice questions based on previous knowledge. These methods can be a good way to evaluate their performance in class daily or weekly.

Secondly, since most students mute themselves and turn off their cameras during online classes, the lecturer cannot easily tell whether they are being fully understood or if students are following the material. Lectures can be effective and easy to comprehend if students follow the lecture appropriately. Teachers should be more careful to check if students are attending the class regularly and attentively. The first and most important thing to implement in an online class is discipline. Teachers can check that every student is attentive in class and encourage the students during class by praising their questions and participation. In addition, lectures will be more effective if the teacher's speech is short, clear, and concise.

Thirdly, teachers can prepare online courses like a live course. This means that teachers should focus on preparing lecture as a real class lecture. Nowadays, there are many online education platforms with countless varieties of functions. Teachers should be ready to utilise the functions of online tools to make their course more active and engaging. For my Speaking Korean class, I found that there is a function in my university platform for students to repeat and record material by themselves following my recorded voice, and later I could check whether the students understood the lecture contents properly.

Fourthly, teachers can always try to create a regular study space and help students stay organised. It is necessary to establish a class environment, whether it is an online class or a face-to-face course. However, online conferences in groups can be more reliable in online classes. The group activities could profoundly improve the involvement of students and raise 
their motivation. Additionally, since they cannot come to college and meet each other in person, they could easy forget their feelings of belonging and identity. By performing the tasks within a group, however, they could contact each other through online conversation even though they are physically far away, and they could achieve higher goals together.

Fifthly, it is very important to keep in mind the potential for distraction during online courses. Every kind of noise can destroy the effectiveness of delivering and attaining knowledge. Voice recordings should be clear and free of other noises. Recorded lectures should include clear voices; any other kind of noise will spoil the lecture for teachers and students. Therefore, it is strongly recommended for lecturers to prepare a high-quality camera and microphone for their recordings. It is essential to have such equipment to ensure a high-quality lecture experience.

\section{Conclusion}

An educational online class provides a greater degree of flexibility in the teaching and learning processes. From research-based analysis, there is less pressure to engage students because of the existence of devices, apps, and multimedia tools to make the learning process more interactive and engaging. It has both pros and cons. It enables the teachers and students to manage their own learning pace, peaceful environment, and preparation or recording of lectures.

Turkey wants to develop its online education system to keep in mind things like faster and more reliable services, high-speed internet, lectures through video apps, webcams, use of microphones or headphones, and multiple cameras. Online education and classes are necessary to continue student growth.

Through research history, everyone has come to know that the online education system has been growing rapidly, but today's reason is maintaining the safety of human life from a deadly disease. We all know the benefits of traditional education, but we also know the problem of today's health crisis. We must improve and develop the online education system and try to compensate for the deficiencies and difficulties of it. Online courses and studies, especially for secondary schools, can be quite beneficial for them to keep students busy with learning activities throughout during the pandemic. However, it may be more costly compared to traditional classes.

Online learning provides time management skills and flexibility to students and motivates them to focus on their own activities without the help of others. These skills will be useful for them when they are adapting to online courses. The hardest part about teaching students in online classes is the continuous distractions around the teachers and students. Some distractions mostly happen at home, like family members, electronic devices, or environmental noise. But for now, we have to overcome these issues and develop the online system of education for the 
International Journal of Innovation, Creativity and Change. www.ijicc.net

Volume 15, Issue 2, 2021

upcoming stars of our country — our students — and the makers of nations — our teachers because it is a matter of their futures.

\section{REFERENCES}

Adnan, M., \& Anwar, K. (2020). Online Learning amid the COVID-19 Pandemic: Students' Perspectives. Online Submission, 2(1), 45-51.

Black, S., Yasukawa, K. \& Brown, T. 2015. The literacy and numeracy 'crisis' in Australian workplaces: Discursive rhetoric vs. production floor realities. Journal of Education and Work, 28(6), 607-630.

Brecht, H. D. (2012). Learning from online video lectures. Journal of Information Technology Education, 11(1), 227-250.

Demirezen, M., Topal I.H.(2015), Fossilized Pronunciation Errors from the Perspectives of Turkish Teachers of English and their Implications, Procedia - Social and Behavioral Sciences, 199(3), 793-800.

Dhawan, S. (2020). Online learning: A panacea in the time of COVID-19 crisis. Journal of Educational Technology Systems, 49(1), 5-22.

Dias, P., Freedman, A., Medway, P., \& Pare, A. (2011). Worlds Apart: Acting and Writing in Academic and Workplace Contexts (First). Routledge Taylor \& Francis.

DiBiase, D. (2000). Is distance teaching more work or less work?. American Journal of Distance Education, 14(3), 6-20.

Grubic, N.; Badovinac, S.; Johri, A.M. (2020). Student mental health in the midst of the COVID-19 pandemic: A call for further research and immediate solutions. International Journal of Social Psychiatry, 66, 517-518.

Isbell, D. R. (2018). Online informal language learning: Insights from a Korean learning community. Language Learning \& Technology, 22(3), 82-102.

Mirkholikovna, D. K. (2020). Advantages and disadvantages of distance learning. Наука и образование сегодня, 7 (54).

Mishra, L., Gupta, T., \& Shree, A. (2020). Online teaching-learning in higher education during lockdown period of Covid-19 pandemic. International Journal of Educational Research Open, 100012.

Mitchell, L. (2020). Best Practices for New Online Management Education Instructors to Overcome Resistance to Online Teaching: New Insights. Mitchell, LD, Best practices for new online management education instructors to overcome resistance to online teaching: New insights, In S. Allen, K. Gower, \& D. Allen (eds.) The Handbook of Teaching with Technology in Management, Leadership, and Business, Edward Elgar Publishing.

Proshkova, Z. V. (2020, May). Advantages of Studying at Online Schools in Assessments of Students' Families. In International Scientific Conference "Digitalization of Education: History, Trends and Prospects” (DETP 2020) (pp. 848-852). Atlantis Press. 
Sundarasen, S., Chinna, K., Kamaludin, K., Nurunnabi, M., Baloch, G. M., Khoshaim, H. B., \& Sukayt, A. (2020). Psychological impact of Covid-19 and lockdown among university students in Malaysia: Implications and policy recommendations. International journal of environmental research and public health, 17(17), 6206.

Toquero, C. M. (2020). Challenges and opportunities for higher education amid the COVID19 pandemic: The Philippine context. Pedagogical Research, 5(4).

Verawardina, U., Asnur, L., Lubis, A. L., Hendriyani, Y., Ramadhani, D., Dewi, I. P., \& Sriwahyuni, T. (2020). Reviewing Online Learning Facing the Covid-19 Outbreak. Talent Development \& Excellence, 12, 385-392.

Woon, J. G., \& May, H. N. J. (2020). Effectiveness of Learning Portfolio for Writing Practice in Korean Language Learning. Pertanika Journal of Social Sciences \& Humanities, 28, 121-137. 